\title{
Ghrelin exerts a proliferative effect on a rat pituitary somatotroph cell line via the mitogen-activated protein kinase pathway
}

Alexandra M Nanzer, Sahira Khalaf, Abdul M Mozid, Robert C Fowkes, Mayur V Patel, Jacky M Burrin, Ashley B Grossman and Márta Korbonits

Department of Endocrinology, St Bartholomew's Hospital, 59 Bartholomew Close, Unit 1.1, London EC1A 7BE, UK

(Correspondence should be addressed to M Korbonits; Email: m.korbonits@qmul.ac.uk)

\begin{abstract}
Objectives: Ghrelin is a brain-gut peptide with GH-releasing and appetite-inducing activities and a widespread tissue distribution. Ghrelin is the endogenous ligand of the GH secretagogue receptor type 1a (GHS-R1a), and both ghrelin and the GHS-R1a are expressed in the pituitary. There are conflicting data regarding the effects of ghrelin on cell proliferation. A positive effect on proliferation and activation of the mitogen-activated protein kinase (MAPK) pathway has been found in hepatoma, adipose, cardiomyocyte and prostate cell lines. However, ghrelin has also been shown to have antiproliferative effects on breast, lung and thyroid cell lines. We therefore examined the effect of ghrelin on the rat pituitary cell line GH3.

Methods: RT-PCR was used for the detection of GHS-R1a and pre-proghrelin mRNA expression in GH3 cells. The effect of ghrelin on cell proliferation was studied using $\left[{ }^{3} \mathrm{H}\right]$ thymidine incorporation; cell counting and the activation of the MAPK pathway were studied using immunoblotting and inhibitors of the extracellular signal-regulated kinase 1 and 2 (ERK 1/2), protein kinase $C$ (PKC) and tyrosine phosphatase pathways.

Results: GHS-R1a and ghrelin mRNA expression were detected in GH3 cells. Ghrelin, at $10^{-10}$ to $10^{-6} \mathrm{M}$ concentrations, significantly increased $\left.{ }^{3} \mathrm{H}\right]$ thymidine incorporation (at $10^{-9} \mathrm{M}, 183 \pm 13 \%$ (means \pm S.E.M.) compared with untreated controls), while 12-phorbol 13-myristate acetate (PMA) at $10^{-7} \mathrm{M}$ (used as a positive control) caused a $212 \pm 14 \%$ increase. A reproducible stimulatory effect of desoctanoyl ghrelin was also observed on $\left[{ }^{3} \mathrm{H}\right]$ thymidine incorporation $(135 \pm 5 \%$; $P<0.01$ at $10^{-9} \mathrm{M}$ compared with control), as well as on the cell count (control $6.8 \times 10^{4} \pm 8.7 \times 10^{3}$ cells $/ \mathrm{ml}$ vs desoctanoyl ghrelin $\left(10^{-9} \mathrm{M}\right) 1.04 \times 10^{5} \pm 7.5 \times 10^{3} \mathrm{cells} / \mathrm{ml}$; $P<0.01)$. Ghrelin caused a significant increase in phosphorylated ERK $1 / 2$ in immunoblotting, while desoctanoyl ghrelin showed a smaller but also significant stimulatory effect. The positive effect of ghrelin and desoctanoyl ghrelin on $\left[{ }^{3} \mathrm{H}\right]$ thymidine incorporation was abolished by the MAPK kinase inhibitor U0126, the PKC inhibitor GF109203X and the tyrosine kinase inhibitor tyrphostin 23, suggesting that the ghrelin-induced cell proliferation of GH3 cells is mediated both via a PKC-MAPK-dependent pathway and via a tyrosine kinase-dependent pathway. This could also be clearly demonstrated by Western blot analysis, where a transient increase in ERK 1/2 phosphorylation by ghrelin was attenuated by all three inhibitors.

Conclusion: We have shown a novel role for ghrelin in stimulating the proliferation of a somatotroph pituitary tumour cell line, suggesting that ERK activation is involved in mediating the effects of ghrelin on cell proliferation. Desoctanoyl ghrelin showed a similar effect. As ghrelin has been shown to be expressed in both normal and adenomatous pituitary tissue, locally produced ghrelin may play a role in pituitary tumorigenesis via an autocrine/paracrine pathway.
\end{abstract}

European Journal of Endocrinology $151233-240$

\section{Introduction}

Ghrelin is a brain-gut peptide with various activities including growth hormone $(\mathrm{GH})$ release via hypothalamic as well as direct pituitary pathways, causing an increase in appetite and direct effects on the exocrine and endocrine pancreatic function, on carbohydrate metabolism, on the cardiovascular system, on gastric acid secretion and on stomach motility, as well as on sleep (1). Ghrelin was identified as the endogenous ligand of the $\mathrm{GH}$ secretagogue receptor type 1a (GHS-R1a), but probably other, currently unidentified, receptors also play a role in its diverse effects $(2,3)$. The 28 amino acid peptide has several variants with similar biological activity, all of these analogues being subject to a unique post-translational modification: 
the hydroxyl group of the third residue serine is esterified by octanoic acid $(4,5)$. Ghrelin is the first natural peptide reported to have this specific modification which is essential for its GH-releasing activity (2). We have previously demonstrated the widespread tissue distribution of ghrelin mRNA in the human, while the expression of the GHS-R1a is much more limited, and it has been suggested that ghrelin may have an even wider role than previously thought with some of these effects probably mediated via a receptor different from the cloned GHS-R1a (6).

There are conflicting reports on the effect of ghrelin on cell proliferation. It has been shown to have an anti-proliferative effect on thyroid, breast and lung cancer cell lines $(7-10)$ whilst other studies have shown a (pro-)proliferative effect on prostate, liver, adrenal, cardiac and adipose cells (11-16). Ghrelin and the GHS-R1a are both present in the pituitary (17), but possible effects on pituitary cell proliferation have not previously been reported.

In this study we have therefore examined whether ghrelin affects proliferation of a somatotroph pituitary tumour cell line, and whether any such effects involve the extracellular signal-related kinase (ERK) family of mitogen-activated protein kinase (MAPK) proteins.

\section{Materials and methods}

\section{Cell culture}

The rat somatotroph cell line GH3 cells were obtained from ATTC (LGC Promochem, Teddington, London, UK) and were grown in monolayer in culture medium containing Dulbecco's modified Eagle's medium supplemented with high glucose $(4500 \mathrm{mg} / \mathrm{l})$ containing $10 \% \quad(\mathrm{v} / \mathrm{v})$ fetal calf serum (FCS), penicillin $(100 \mathrm{IU} / \mathrm{ml})$, streptomycin $(100 \mu \mathrm{g} / \mathrm{ml})$ and fungizone (125 mg/l) (Life Technologies, Paisley, Strathclyde, UK). Cells were cultured at $37^{\circ} \mathrm{C}$ in a humidified atmosphere of $95 \%$ air and $5 \% \mathrm{CO}_{2}$. Cells were plated at a density of $1 \times 10^{6}$ cells/well in six-well plates for Western blotting for ERK, and $5 \times 10^{4}$ cells/well in 24-well plates for the proliferation studies.

\section{RT-PCR}

Total RNA was prepared from $10^{6}$ cultured GH3 cells using the SV total RNA isolation system (Promega, Southampton, Hants, UK), which includes a deoxyribonuclease step, according to the manufacturer's instructions, and cDNA was synthesized as described previously (18). Omission of reverse transcriptase and water replacing the ribonucleic acid template were used as a negative controls. The PCR was performed using intron-spanning rat GHS-R 1a primers (5'-CTCATCGGGAGGAAGCTATG-3' sense and 5'-CAGGTTGCAGTACTGGCTGA-3' antisense; GenBank number U94321) and ghrelin primers (5'-TGAGCCCAGAGCACCAGAAA-3' sense and 5' - CTGAGCTCCTGACAGCTTGA-3' antisense; GenBank number AB029433). The PCR mixture consisted of $5 \mu \mathrm{l}$ cDNA, $1 \mu \mathrm{l} 20 \mathrm{mM}$ rat GHS-R1a primers or rat ghrelin primers, $2.5 \mu \mathrm{l} 10 \times$ Taq buffer, $1.5 \mu \mathrm{l}$ $\mathrm{MgCl}_{2}(1.5 \mu \mathrm{M}), 0.25 \mu \mathrm{l}$ dNTP $(20 \mathrm{mM}), 0.125 \mu \mathrm{l} \mathrm{Taq}$ enzyme (Promega) and $13.625 \mu \mathrm{l}$ water to a final volume of $25 \mu \mathrm{l}$. The reaction mixture was subjected to 40 cycles of PCR amplification consisting of denaturation for $60 \mathrm{~s}$ at $94^{\circ} \mathrm{C}$, annealing for $60 \mathrm{~s}$ at $55^{\circ} \mathrm{C}$ and extension for $60 \mathrm{~s}$ at $72{ }^{\circ} \mathrm{C}$, after an initial denaturation for $5 \mathrm{~min}$ at $95^{\circ} \mathrm{C}$. A final extension cycle of $10 \mathrm{~min}$ at $72{ }^{\circ} \mathrm{C}$ was used. The oligonucleotide primers allowed amplification of a 216 base pair GHS-R1a and a 188 base pair ghrelin product, which were verified by restriction enzyme analysis and sequencing.

\section{[3]thymidine incorporation}

GH3 cells were plated at $5 \times 10^{4}$ cells/well in media containing 2\% charcoal-stripped FCS and various concentrations of ghrelin, desoctanoylated ghrelin and 12-phorbol 13-myristate acetate (PMA; $10^{-7} \mathrm{M}$ ) or epidermal growth factor (EGF; $10^{-8} \mathrm{M}$; positive control; $\mathrm{CN}$ Biosciences, Nottingham, Notts, UK) for $72 \mathrm{~h}$ with the addition of $2 \mu \mathrm{Ci} /$ well $\left[{ }^{3} \mathrm{H}\right]$ thymidine (Amersham International plc, Amersham, Bucks, UK) for a further $6 \mathrm{~h}$. A time-course of $24 \mathrm{~h}, 48 \mathrm{~h}$ and $72 \mathrm{~h}$ was performed for ghrelin stimulation and $72 \mathrm{~h}$ was selected for further experiments. Studies were also performed to investigate the effect of rat ghrelin or desoctanoyl ghrelin-induced (a kind gift from M Kojima, Kurume University, Fukuoka, Japan) proliferation and the effect of U0126 (an MAPK kinase (MEK) inhibitor), GF109203X (a protein kinase C (PKC) inhibitor; both from CN Biosciences), tyrphostin 23 (a tyrosine kinase inhibitor; Sigma, Poole, Dorset, UK), wortmannin (a phosphatidylinositol 3-kinase (PI(3)K) inhibitor; $\mathrm{CN}$ Biosciences) and H-89 (a protein kinase A (PKA) inhibitor; Sigma) upon ghrelin-induced MAPK stimulation. In these experiments U0126 was used at $10^{-6} \mathrm{M}$, a concentration previously reported to block half-maximal ERK activity (19), GF109203X at $10^{-6} \mathrm{M}(20)$ and $10^{-8} \mathrm{M}$, tyrphostin at $10^{-5} \mathrm{M}(14)$, wortmannin at $5 \times 10^{-9} \mathrm{M}(21)$ and $\mathrm{H} 89$ at $10^{-7} \mathrm{M}$ (22). Inhibitors were added $30 \mathrm{~min}$ before each treatment. Cells were harvested before counting in the presence of scintillation fluid using a Microbeta $1450 \beta$ counter (Wallac, Turku, Finland). Experiments were repeated at least three times.

\section{Cell count}

GH3 cells were plated at $5 \times 10^{4}$ cells/well in media containing 2\% charcoal-stripped FCS and were treated with stimulators and inhibitors as above. Cell number was counted $24 \mathrm{~h}, 48 \mathrm{~h}$ and $72 \mathrm{~h}$ after treatment. 


\section{Protein extractions and measurement of ERK}

Serum-starved GH3 cells were treated with $10^{-6} \mathrm{M}$ to $10^{-10} \mathrm{M}$ ghrelin, $10^{-9} \mathrm{M}$ desoctanoylated ghrelin or $10^{-7} \mathrm{M}$ PMA as a positive control. In the inhibitory studies, $10^{-6} \mathrm{M}$ U0126, $10^{-6} \mathrm{M}$ and $10^{-8} \mathrm{M}$ GF109203X or $10^{-5} \mathrm{M}$ tyrphostin 23 were added $30 \mathrm{~min}$ before treatment. After stimulation for 5 or $15 \mathrm{~min}$, the cells were washed briefly with ice-cold phosphate-buffered saline (PBS) before treatment with Cytobuster protein extraction reagent (Novagen, $\mathrm{CN}$ Biosciences) and a phosphatase inhibitor, phosphatase cocktail I and II (Sigma). Cells were incubated on ice for a further $5 \mathrm{~min}$. The protein concentration of the lysates was normalized using the Bradford assay (Bio-Rad, Hemel Hempstead, Middx, UK). Typically, $7-30 \mu \mathrm{g}$ samples were subjected to $10 \%$ SDS-PAGE separation, with protein transfer to polyvinylidene difluoride (PVDF) membrane. The membrane was blocked with $5 \%$ non-fat milk for 90 min and incubated overnight at $4{ }^{\circ} \mathrm{C}$ using anti-phosphorylated ERK $1 / 2$ or anti-total ERK 1/2 (both at 1:1000) as the primary antibodies (Promega). The membrane was washed three times with PBS containing 0.05\% Tween and subsequently incubated with horseradish peroxidaseconjugated anti-rabbit antibody as the secondary antibody (1:10 000; Dako, Glostrup, Denmark) for $2 \mathrm{~h}$ at room temperature. A chemiluminescent peroxidase substrate, ECL Plus (Amersham-Pharmacia, Amersham, Bucks, UK), was applied according to the manufacturer's instructions, and the membranes were exposed briefly to X-ray film. Total ERK 1 and 2 (ERK $1 / 2$ ) was determined by stripping the PVDF membrane with $0.985 \mathrm{~g}$ Tris-hydrochloride, $2 \mathrm{~g}$ SDS, $781 \mu \mathrm{l} 2-$ mercaptoethanol $(\mathrm{pH} 4)$, and re-probing for the total with anti-total ERK 1/2 antibody. Densitometric readings of the resulting bands were evaluated using the Scientific Imaging system (Kodak, New Haven, CT, USA). Experiments were repeated at least three times.

\section{Data presentation and analysis}

The data were analysed using the StatsDirect computer software program (I Buchan, Cambridge, Cambs, UK). The data were not normally distributed, as assessed by the Shapiro-Wilk test. The Kruskal-Wallis test was therefore used followed by the Conover-Inman test. The data were calculated from at least three separate experiments and are shown as means \pm s.E.M. Significance was taken at $P<0.05$.

\section{Results}

GHS-R1a and pre-proghrelin mRNAs were shown to be expressed by the GH3 pituitary somatotroph cell line using RT-PCR (Fig. 1). PMA caused the expected increase in $\left[{ }^{3} \mathrm{H}\right]$ thymidine incorporation of GH3 cells after $72 \mathrm{~h}$ of treatment $(212 \pm 14 \%$ above untreated

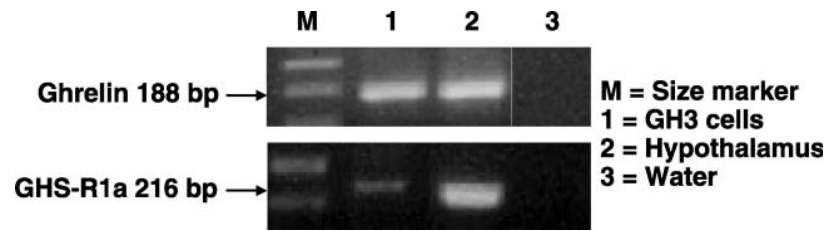

Figure 1 Expression of ghrelin and GHS-R1a mRNA in the GH3 pituitary tumour cell line. $\mathrm{H}_{2} \mathrm{O}$ was used as a negative control, rat hypothalamic CDNA as a positive control for GHS-R1a expression. Size marker: $\Phi \times 174 /$ Hinf1.

controls; $P<0.001$; Fig. 2). Ghrelin significantly increased proliferation at $10^{-10}$ to $10^{-6} \mathrm{M}$ concentrations $\left(10^{-10} \mathrm{M} \quad 134 \pm 8 \% \quad(P<0.01), \quad 10^{-9} \mathrm{M}\right.$ $183 \pm 13 \%(P<0.001), 10^{-7} \mathrm{M} 134 \pm 5 \%(P<0.01)$, $\left.10^{-6} \mathrm{M} 153 \pm 12 \%(P<0.001)\right)$ above untreated controls, suggesting increased DNA synthesis of GH3 cells. A dose-response curve with desoctanoylated ghrelin at $10^{-6}$ to $10^{-12} \mathrm{M}$ also showed a significant increase in proliferation at $10^{-10}$ to $10^{-6} \mathrm{M}$ concentrations $\left(10^{-10} \mathrm{M} \quad 149 \pm 18 \% \quad(P<0.01), \quad 10^{-9} \mathrm{M} \quad 149 \pm 8 \%\right.$ $(P<0.01), \quad 10^{-8} \mathrm{M} \quad 139 \pm 3 \% \quad(P<0.01), \quad 10^{-6} \mathrm{M}$ $151 \pm 16 \%(P<0.01)$; Fig. 2$)$.

We next studied the effect of the inhibitors $10^{-6} \mathrm{M}$ U0126, $10^{-6} \mathrm{M}$ and $10^{-8} \mathrm{M}$ GF109203X and $10^{-5} \mathrm{M}$ tyrphostin 23, on ghrelin-activated cell proliferation. The effect of these inhibitors on their appropriate pathways are shown in Fig. 3: $10^{-7} \mathrm{M}$ PMA (known to activate the PKC-MAPK pathway) and $10^{-8} \mathrm{M}$ EGF (which activates the tyrosine kinase-MAPK pathway) and inhibitors for both pathways were used. The PKC inhibitor GF109203X inhibited the effect of PMA, but

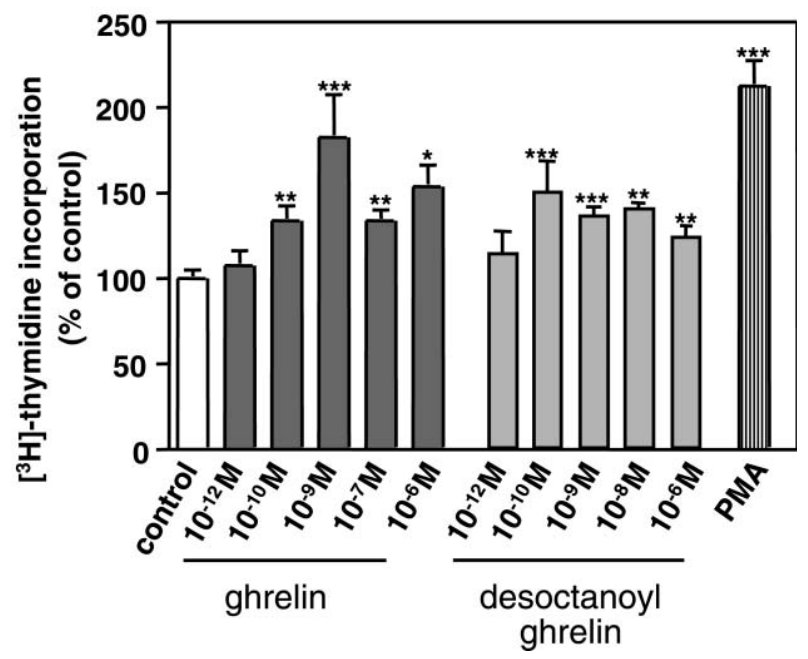

Figure 2 Dose-response curve of the effect of ghrelin and desoctanoyl ghrelin on $\left[{ }^{3} \mathrm{H}\right]$ thymidine incorporation in $\mathrm{GH} 3$ cells. Cells were plated out at $5 \times 10^{4}$ cells per well of a 24 -well plate in charcoal-stripped culture medium alone (control), ghrelin and desoctanoyl ghrelin $\left(10^{-12}\right.$ to $\left.10^{-6} \mathrm{M}\right)$ and PMA $\left(10^{-7} \mathrm{M}\right.$; positive control) and incubated for $72 \mathrm{~h}$. Results are expressed as fold increase over basal incorporation and shown as means \pm S.E.M. $(n=8-36)$. Significance is relative to the control. ${ }^{\star} P<0.05$, ${ }^{\star *} P<0.01$, ${ }^{* * *} P<0.001$. 


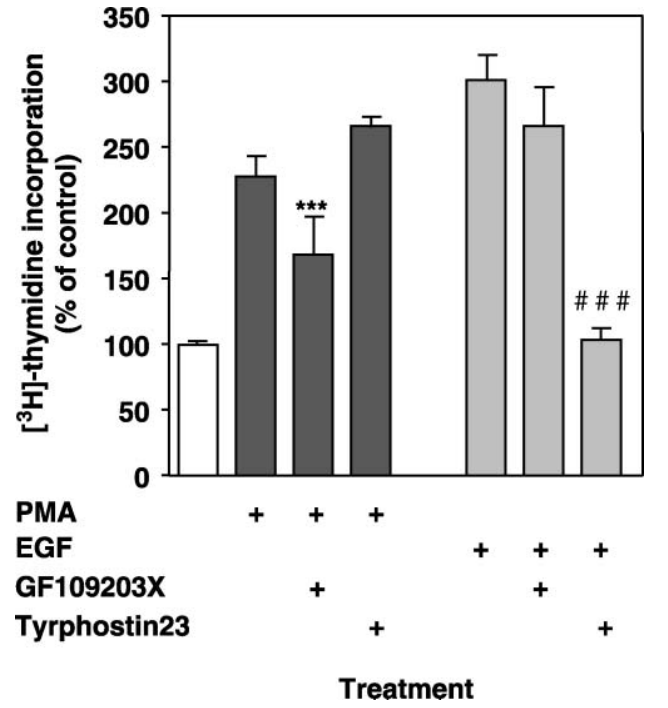

Figure 3 The effect of the PKC inhibitor GF109203X $\left(10^{-8} \mathrm{M}\right)$ and the tyrosine kinase inhibitor tyrphostin $23\left(10^{-5} \mathrm{M}\right)$ on PMA$\left(10^{-7} \mathrm{M}\right)$ and EGF $\left(10^{-8} \mathrm{M}\right)$-induced proliferation. Results are expressed as fold increase over basal incorporation and shown as means \pm S.E.M. $(n=4-12) .{ }^{* *} P<0.001$ vs PMA, ${ }^{\# \# \#} P<0.001$ vs EGF.

not EGF, while the tyrosine kinase inhibitor tyrphostin 23 inhibited the effect of EGF, but not PMA, as expected (Fig. 3). $10^{-9} \mathrm{M}$ and $10^{-6} \mathrm{M}$ ghrelin-induced proliferation $(183 \pm 13 \%$ and $153 \pm 12 \%)$ was significantly attenuated by $10^{-6} \mathrm{M}$ U0126 $(96 \pm 11 \%$ and $90 \pm 9 \%$ respectively; $P<0.001$ for both compared with ghrelin at $10^{-9} \mathrm{M}$ and $10^{-6} \mathrm{M}$ alone; Fig. $4 \mathrm{~A}$ and $\mathrm{B}$ ). GF109203X showed inhibition at both concentrations used; GF109203X at $10^{-8} \mathrm{M}$ compared with ghrelin at $10^{-9} \mathrm{M}$ and ghrelin at $10^{-6} \mathrm{M} 78 \pm 10 \%(P<0.0001)$ and $71 \pm 8 \%(P<0.01)$, and GF109203X at $10^{-6} \mathrm{M}$ $44 \pm 3 \%$ and $52 \pm 1 \%$ (both $P<0.0001$ ). Furthermore,
$10^{-5} \mathrm{M}$ tyrphostin 23 caused significant inhibition of the cell proliferation caused by $10^{-9} \mathrm{M}$ and $10^{-6} \mathrm{M}$ ghrelin $(86 \pm 4 \%$ and $81 \pm 4 \% ; P<0.001$ for both; Fig. $4 \mathrm{~A}$ and $\mathrm{B})$. The inhibitors on their own all significantly inhibited cell proliferation compared with the control: $10^{-6} \mathrm{M}$ U0126 $74 \pm 5 \% \quad(P<0.05)$, $10^{-8} \mathrm{M}$ GF109203X 65 $12 \% \quad(P<0.01), \quad 10^{-6} \mathrm{M}$

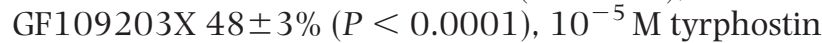
$2375 \pm 2 \%(P<0.01$; Fig. 4C). The inhibition caused by the inhibitors was much greater for the ghrelin-stimulated response than the inhibition of the unstimulated proliferation: for example, the proliferation induced by $10^{-9} \mathrm{M}$ ghrelin was reduced by U0126 by $87 \%$ while the change for basal proliferation was inhibited only by $26 \%$. Similar to ghrelin, the effect of desoctanoyl ghrelin on thymidine incorporation was inhibited by all three inhibitors (U0126 62\%, 10 ${ }^{-8} \mathrm{M} \mathrm{GF} 109203 \mathrm{X} 84 \%$ and tyrphostin 23 34\%; $P<0.01$ for each). The treatment of cells with $10^{-9} \mathrm{M}$ and $10^{-6} \mathrm{M}$ ghrelin combined with EGF or PMA showed no inhibition or synergism of the proliferative effect (data not shown).

Desoctanoyl ghrelin significantly increased cell numbers compared with normals at 48 and $72 \mathrm{~h}$ of incubation (at $72 \mathrm{~h}$, control $6.8 \times 10^{4} \pm 8.7 \times 10^{3} \mathrm{cells} / \mathrm{ml}$ vs $10^{-9} \mathrm{M}$ desoctanoyl ghrelin $1.04 \times 10^{5} \pm 7.5 \times 10^{3}$ cells $/ \mathrm{ml} ; P<0.01$ ), while the effect was significantly inhibited by U0126 $\left(2.38 \times 10^{4} \pm 5.5 \times 10^{3} \mathrm{cells} / \mathrm{ml}\right.$; $P<0.001$ ) (Fig. 5).

The PI(3)K inhibitor wortmannin (used at a concentration of $5 \times 10^{-9} \mathrm{M}$ ) and the PKA inhibitor H-89 (used at $10^{-7} \mathrm{M}$ ) failed to inhibit ghrelin-induced proliferation (data not shown).

The effect of ghrelin on phosphorylated ERK $1 / 2$ was evaluated with immunoblotting with PMA as positive control. Stimulation of GH3 cells with ghrelin $\left(10^{-6} \mathrm{M}\right.$ to $\left.10^{-10} \mathrm{M}\right)$ led to an increase in the amount of phosphorylated ERK 1/2 (Fig. 6A). Maximal

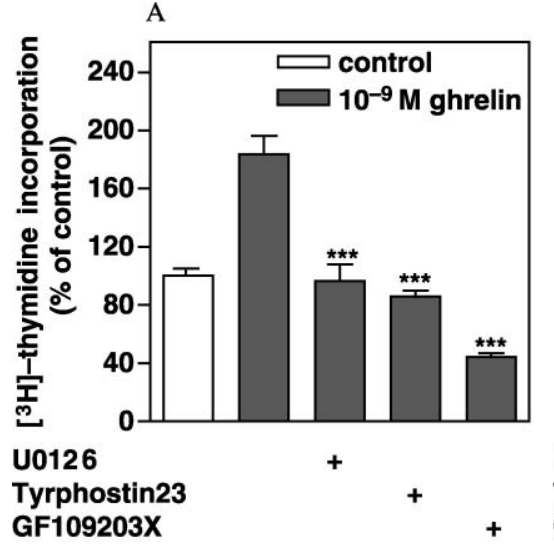

Treatment

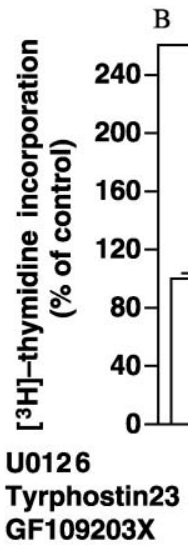

B

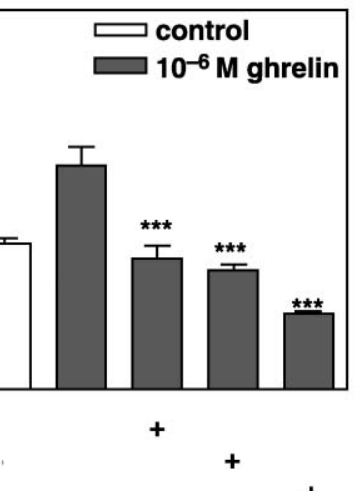

Treatment

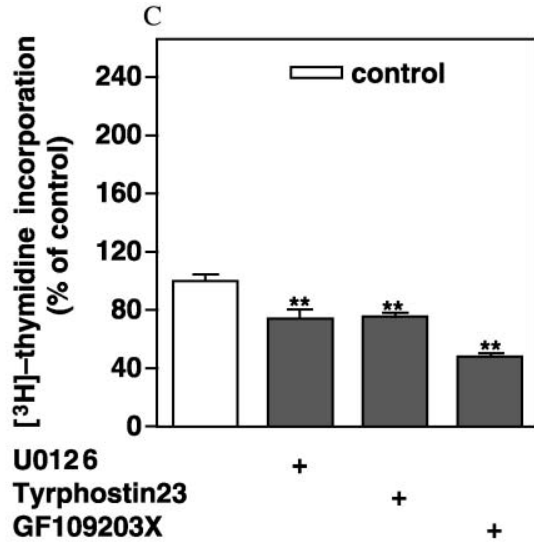

Treatment

Figure 4 The effect of the MEK inhibitor U0126 $\left(10^{-6} \mathrm{M}\right)$, the PKC inhibitor GF109203X $\left(10^{-6} \mathrm{M}\right)$ and the tyrosine kinase inhibitor tyrphostin $23\left(10^{-5} \mathrm{M}\right)$ on basal and ghrelin-induced $\left.{ }^{3} \mathrm{H}\right]$ thymidine incorporation in GH3 cells. Cells were treated with charcoal-stripped culture medium alone (control) or $(A)$ ghrelin $\left(10^{-9} \mathrm{M}\right)$, (B) ghrelin $\left(10^{-6} \mathrm{M}\right)$, with or without a pretreatment of the inhibitors for 30 min. Treatment with inhibitors on their own are shown in $(C)$. Results are expressed as fold increase over basal incorporation and shown as means \pm S.E.M. $(n=16-36)$. ${ }^{* \star *} P<0.001$ compared with ghrelin (A and B); ${ }^{* *} P<0.01$ compared with control (C). 


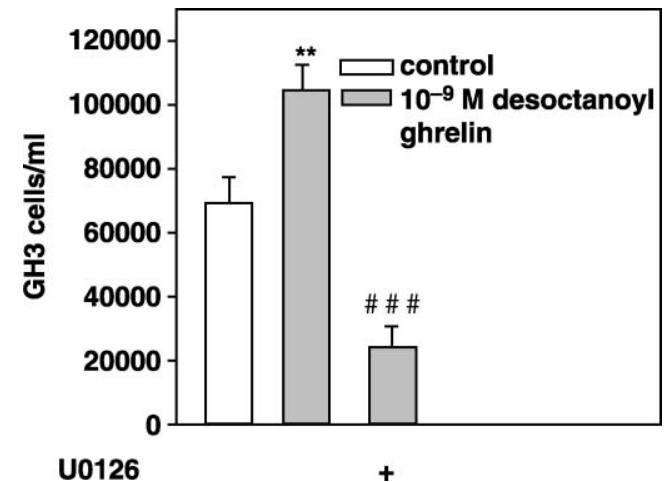

Figure 5 The effect of desoctanoyl ghrelin $\left(10^{-9} \mathrm{M}\right)$ is shown on GH3 cell numbers. Cells were plated out at $5 \times 10^{4}$ cells per well of a 24-well plate in charcoal-stripped culture medium alone (control), desoctanoyl ghrelin $\left(10^{-9} \mathrm{M}\right)$ and with a pretreatment of U0126 $\left(10^{-6} \mathrm{M}\right)$ for $30 \mathrm{~min}$ and incubated for $72 \mathrm{~h}$. Results are expressed as cell number $/ \mathrm{ml}$ and shown as means \pm S.E.M. $(n=4)$. ${ }^{\star *} P<0.01$ relative to the control, ${ }^{\# \# \#} P<0.001$ relative to desoctanoyl ghrelin.

phosphorylation was reached at $5 \mathrm{~min}$, with a slight attenuation at $15 \mathrm{~min}$. Similar to the proliferation studies, desoctanoylated ghrelin also showed increased activation of ERK 1/2 compared with control $(P<0.01$; Fig. 6B).

To assess the effect of signalling pathway inhibitors on ERK 1/2 phosphorylation, cells were pretreated with the MEK inhibitor U0126, the tyrosine kinase inhibitor tyrphostin 23 and the PKC inhibitor GF109203X at the concentrations described above. Similar to the proliferation studies, GF109203X inhibited the action of PMA while tyrphostin 23 inhibited the effect of EGF, but not vice versa (data not shown). All three inhibitors blocked the ghrelin-stimulated increase in ERK 1/2 phosphorylation (Fig. 7). These results suggested that the signalling cascade from ghrelin to the ERK is mediated through $\mathrm{PKC}$ as well as transactivation via the tyrosine kinase pathways.

\section{Discussion}

These studies provide novel evidence that ghrelin stimulates proliferation of the GH3 pituitary somatotroph tumour cell line. It also suggests that ERK activation mediates this effect. Both these effects may be mediated through the GHS-R 1a, shown to be expressed in these cells. Our finding may link circulating or locally produced ghrelin to pituitary tumorigenesis via an autocrine/paracrine pathway. Indeed, ghrelin mRNA is expressed in pituitary tumours with the highest levels in non-functioning pituitary adenomas; however, the level of ghrelin mRNA expression did not correlate with tumour size or with the grading of the tumours $(17,23)$. It has been demonstrated that GHS-R1a mRNA expression is increased in some somatotroph tumours, suggesting that the receptor may be a promoting factor in tumorigenesis $(17,24)$. A study in prostate cancer cell lines (11) has shown co-expression of the GHS-R 1a and ghrelin, as in pituitary cells, and demonstrated increased cell proliferation in vitro in response to ghrelin, implying a potential promoting role for ghrelin in this tissue. Similarly, cultured adrenal zona glomerulosa cells also showed an increased rate of proliferation (14). Ghrelin also activates the MAPK pathway and prevents apoptosis in cultured primary or $\mathrm{H9c} 2$ cardiomyocytes (16). Baldanzi et al. suggest

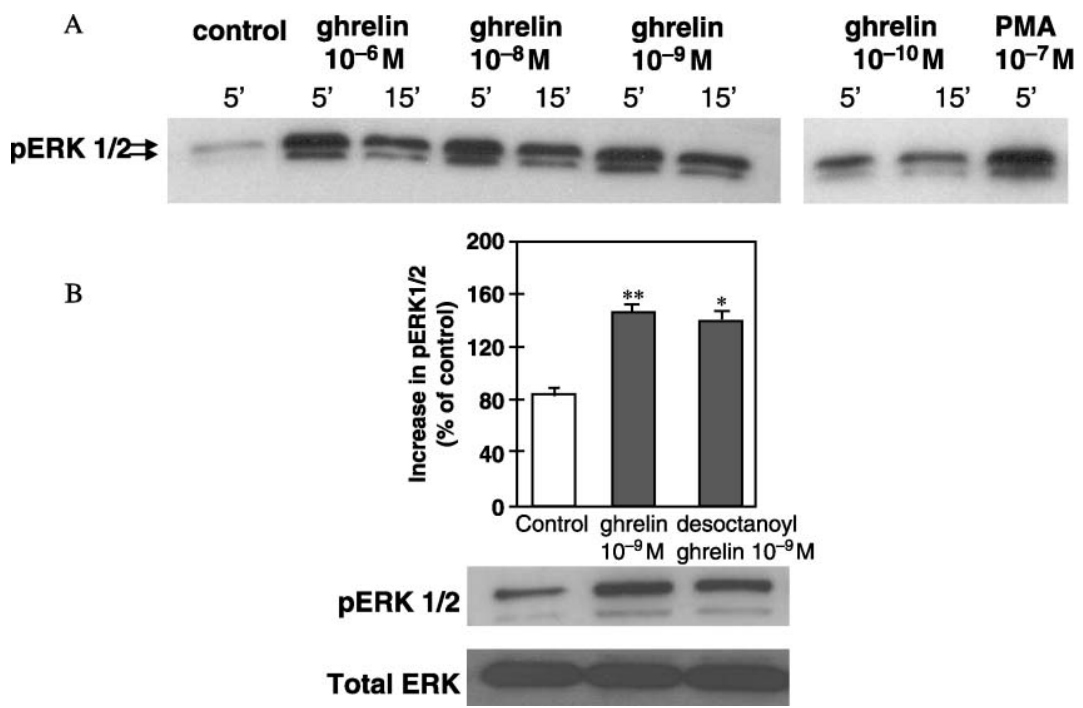

Figure 6 (A) ERK 1/2 MAPK activation in GH3 cells by ghrelin $\left(10^{-6}\right.$ to $\left.10^{-10} \mathrm{M}\right)$. Serum-starved GH3 cells were treated with increasing concentration of ghrelin and with PMA $\left(10^{-7} \mathrm{M}\right.$; positive control) for 5 or $15 \mathrm{~min}$. MAPK activation was determined by Western blotting for phosphorylated MAPK (pERK 1/2). (B) The effect of ghrelin $\left(10^{-9} \mathrm{M}\right)$ and desoctanoyl ghrelin $\left(10^{-9} \mathrm{M}\right)$ on $\mathrm{pERK} 1 / 2$ activation. Total ERK $1 / 2$ MAPK was determined by stripping the PVDF membrane and reprobing for total ERK. The results are shown as means \pm S.E.M. ${ }^{\star} P<0.05,{ }^{*} P<0.01$ compared with control. 


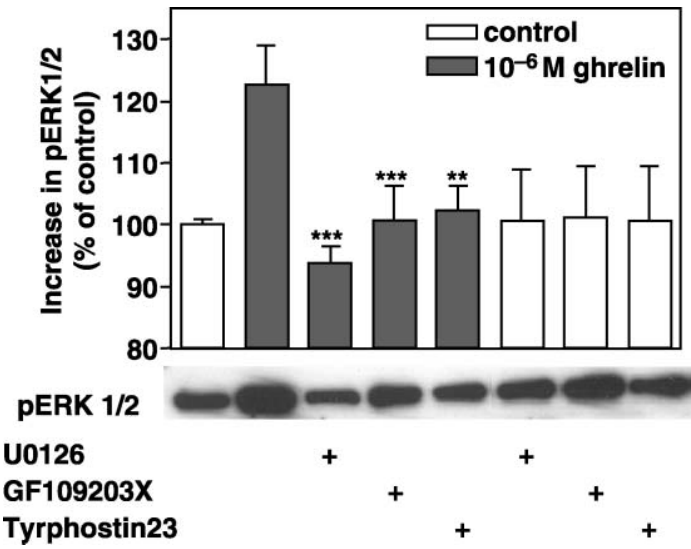

Figure 7 Changes of the phosphorylation status of phosphorylated (p) ERK 1/2 in GH3 cells in response to ghrelin $\left(10^{-9} \mathrm{M}\right)$, ghrelin $\left(10^{-9} \mathrm{M}\right)$ pretreated with $10^{-6} \mathrm{M} \mathrm{U} 0126,10^{-6} \mathrm{M}$ GF109203X or $10^{-5} \mathrm{M}$ tyrphostin 23 , and the three inhibitors on their own. Serum-starved GH3 cells were treated for $5 \mathrm{~min}$. Immunoblots were measured by an imaging densitometer and the values expressed in arbitrary units. Data represent the percent stimulation compared with control (means \pm S.E.M.). ${ }^{* \star} P<0.01$, ${ }_{\star \star \star \star} P<0.001$.

that ghrelin inhibits cell death by activating at least two survival signalling pathways conveyed by ERK $1 / 2$ and PI(3)K/Akt (16). Ghrelin-stimulated cell proliferation seen in this study may occur directly via the MAPK pathway involving the GHS-R1a (Fig. 8). The MAPK pathway consists of a cascade of signalling molecules that sequentially activate each other by phosphorylation, the final messenger being able to migrate to the nucleus to phosphorylate transcription factors involved in gene transcription. Mammalian cells contain three major classes of MAPK, the extracellular signal-related

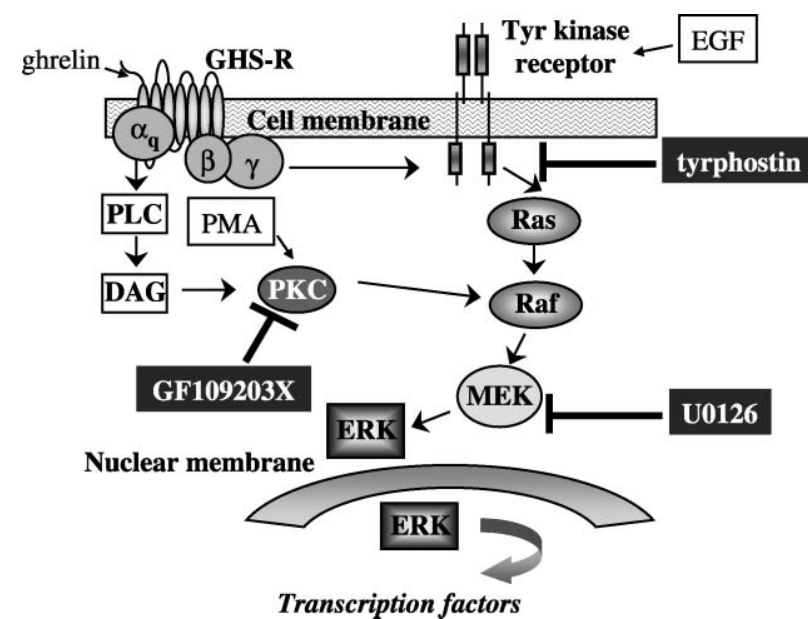

Figure 8 Suggested mechanisms of the effect of ghrelin on MAPK activation. Ghrelin activates the GHS-R1a receptor. Via the $\alpha$ subunit of this receptor the PLC-PKC pathway is activated and Raf-MEK-MAPK activation occurs. Activation of the GHS$\mathrm{R} 1 \mathrm{a}$ also leads to transactivation of a tyrosine kinase receptor via the $\beta$ and $\gamma$ subunits, which activates MAPK via the Ras-RafMEK pathway. PLC, phospholipase C; DAG, diacylglycerol. kinases, c-Jun N-terminal kinase/stress-activated protein kinases and p38 MAPK (25). However, the MAPKs ERK 1/2 are thought to be key signalling molecules in the control of gene transcription events that lead to cell proliferation. It is now well established that not just cytokine and growth factor receptors but also $G$ protein-coupled receptors can stimulate the MAPK pathway (26). We have, for example, shown that pituitary adenylate cyclase-activating polypeptide can stimulate ERK 1/2 via its $G$ protein-coupled receptor (GPCR), stimulating phospholipase C and PKC (27), and similar effects have been demonstrated for other Gq-coupled receptors such as gonadotrophin-releasing hormone and thyrotrophin-releasing hormone (28, 29). Interestingly, it has recently been demonstrated that peptides with receptors primarily working via the cAMP pathway can also activate the PKC pathway and cause activation of MAPK (30). The transactivation of the tyrosine kinase pathway by GPCRs has been well established, probably acting via the $\beta$ and $\gamma$ subunits of the $\mathrm{G}$ protein $(31,32)$. The GHS-R1a belongs to the family of receptors operating via the Gq-phospholipase C (PLC) pathway (33). Receptors operating via this specific pathway have been shown to transactivate tyrosine kinase receptors $(34,35)$. It has been suggested that in adrenal cells the proliferative effect of ghrelin is via the tyrosine kinase pathway and independent of PKC, as a PKC inhibitor did not attenuate the effect of ghrelin while the tyrosine kinase inhibitor did (14). Our studies suggest a slightly different mechanism in the pituitary as an inhibitory effect of both a tyrosine kinase inhibitor as well as a PKC inhibitor was observed (Figs 4, 7 and 8). The mechanism of the effect of ghrelin on MAPK activation could include the activation of the GHS-R1a receptor, although some data point to the involvement of alternative pathways. Via the $\alpha$ subunit of this receptor the PLC-PKC pathway is activated and Raf-MEKMAPK activation occurs. Activation of the GHS-R 1a also leads to transactivation of a tyrosine kinase receptor via the $\beta$ and $\gamma$ subunits, which activates MAPK via the Ras-Raf-MEK pathway. We found no effect of PKA inhibitor $\mathrm{H} 89$ and $\mathrm{PI}(3) \mathrm{K}$ inhibitor wortmannin on the ghrelin-induced cell proliferation. The cytoprotective effect of ghrelin on apoptosis in cardiomyocytes was abolished by wortmannin, but higher doses $\left(10^{-7} \mathrm{M}\right)$ were used in that study (16). The presence of multiple intracellular mechanisms has been previously demonstrated in other systems (36). The different effects of ghrelin or its analogues on cell proliferation in different cell types is intriguing, but could be explained by differences in the specific array of second messengers and transcription factors available in a specific tissue (37). Parallel demonstration of these opposite effects using the same experimental set up and conditions would be of considerable interest. We have shown earlier that Chinese hamster ovary $(\mathrm{CHO})$ cells do not contain functional GHS receptors (38) 
and currently we are studying the effect of ghrelin and des-octanoyl ghrelin on the proliferation of $\mathrm{CHO}$ cells with and without transfection with the human GHS-R.

Ghrelin in its active, octanoylated form stimulates calcium release and $\mathrm{GH}$ release both in vivo and in vitro, while the desoctanoyl form, which is present at a much higher concentration in the circulation as well as in tissues, is completely inactive regarding these effects $(2,17)$. The majority of the studies investigating the various effects of ghrelin have not studied the effect of desoctanoyl ghrelin. However, desoctanoyl ghrelin has been shown to have an anti-proliferative effect in breast cancer lines (9) and it can prevent apoptosis in cardiomyocytes via the MAPK pathway (16). Our results, showing a significant effect of desoctanoyl ghrelin on cell proliferation, which can be inhibited by all the three inhibitors used, and its effect on phosphorylated ERK $1 / 2$ activation in GH3 cells, are therefore not completely unexpected. Despite the presence of GHS-R1a mRNA in GH3 cells (39), similar to GHreleasing hormone, GHSs do not release $\mathrm{GH}$ from this cell line (40). Future studies are necessary to investigate the effects of desoctanoyl ghrelin and identify whether it acts via the classical GHS-R1a receptor or via alternative mechanisms.

In summary, we have shown that ghrelin as well as desoctanoyl ghrelin causes stimulation of GH3 cell proliferation via activation of the MAPK pathway.

\section{Acknowledgements}

A M N was supported by the Novartis Jubilee Foundation and the Uarda Frutiger Foundation, A M M was supported by the PPP Healthcare Medical Trust and M K by the Medical Research Council.

\section{References}

1 Korbonits M, Goldstone AP, Gueorguiev M \& Grossman AB. Ghrelin - a hormone with multiple functions. Front Neuroendocrinology $20042527-68$

2 Kojima M, Hosoda H, Date Y, Nakazato M, Matsuo H \& Kangawa K. Ghrelin is a growth-hormone-releasing acylated peptide from stomach. Nature $1999 \mathbf{4 0 2} 656-660$.

3 Inui A. Ghrelin: an orexigenic and somatotrophic signal from the stomach. Nature Review Neuroscience 20012 551-560.

4 Hosoda H, Kojima M, Matsuo H \& Kangawa K. Purification and characterization of rat des-Gln14-Ghrelin, a second endogenous ligand for the growth hormone secretagogue receptor. Journal of Biological Chemistry 2000275 21995-22000.

5 Hosoda H, Kojima M, Mizushima T, Shimizu S \& Kangawa K. Structural divergence of human ghrelin. Identification of multiple ghrelin-derived molecules produced by post-translational processing. Journal of Biological Chemistry 2003278 64-70.

6 Gnanapavan S, Kola B, Bustin SA, Morris DG, McGee P, Fairclough P, Bhattacharya S, Carpenter R, Grossman AB \& Korbonits M. The tissue distribution of the mRNA of ghrelin and subtypes of its receptor, GHS-R, in humans. Journal of Clinical Endocrinology and Metabolism 200287 2988-2991.

7 Cassoni P, Papotti M, Catapano F, Ghe C, Deghenghi R, Ghigo E \& Muccioli G. Specific binding sites for synthetic growth hormone secretagogues in non-tumoral and neoplastic human thyroid tissue. Journal of Endocrinology 2000165 139-146.

8 Volante M, AllIa E, Fulcheri E, Cassoni P, Ghigo E, Muccioli G \& Papotti M. Ghrelin in fetal thyroid and follicular tumors and cell lines: expression and effects on tumor growth. American Journal of Pathology 2003162 645-654.

9 Cassoni P, Papotti M, Ghe C, Catapano F, Sapino A, Graziani A, Deghenghi R, Reissmann T, Ghigo E \& Muccioli G. Identification, characterization, and biological activity of specific receptors for natural (ghrelin) and synthetic growth hormone secretagogues and analogs in human breast carcinomas and cell lines. Journal of Clinical Endocrinology and Metabolism 200186 1738-1745.

10 Ghe C, Cassoni P, Catapano F, Marrocco T, Deghenghi R, Ghigo E, Muccioli G \& Papotti M. The antiproliferative effect of synthetic peptidyl GH secretagogues in human CALU-1 lung carcinoma cells. Endocrinology $2002143484-491$.

11 Jeffery PL, Herington AC \& Chopin LK. Expression and action of the growth hormone releasing peptide ghrelin and its receptor in prostate cancer cell lines. Journal of Endocrinology $2002 \mathbf{1 7 2}$ $\mathrm{R} 7-\mathrm{R} 11$.

12 Jeffery PL, Herington AC \& Chopin LK. The potential autocrine/ paracrine roles of ghrelin and its receptor in hormone-dependent cancer. Cytokine Growth Factor Reviews 2003 14 113-122.

13 Murata M, Okimura Y, Iida K, Matsumoto M, Sowa H, Kaji H, Kojima M, Kangawa K \& Chihara K. Ghrelin modulates the downstream of insulin signaling in hepatoma cells. Journal of Biological Chemistry $2002 \mathbf{2 7 7} 5667-5674$.

14 Andreis PG, Malendowicz LK, Trejter M, Neri G, Spinazzi R, Rossi GP \& Nussdorfer GG. Ghrelin and growth hormone secretagogue receptor are expressed in the rat adrenal cortex: evidence that ghrelin stimulates the growth, but not the secretory activity of adrenal cells. FEBS Letters 2003536 173-179.

15 Choi K, Roh SG, Hong YH, Shrestha YB, Hishikawa D, Chen C, Kojima M, Kangawa K \& Sasaki S. The role of ghrelin and growth hormone secretagogues receptor on rat adipogenesis. Endocrinology $2003 \mathbf{1 4 4} 754-759$.

16 Baldanzi G, Filigheddu N, Cutrupi S, Catapano F, Bonissoni S, Fubini A, Malan D, Baj G, Granata R, Broglio F, Papotti M, Surico N, Bussolino F, Isgaard J, Deghenghi R, Sinigaglia F, Prat M, Muccioli G, Ghigo E \& Graziani A. Ghrelin and des-acyl ghrelin inhibit cell death in cardiomyocytes and endothelial cells through ERK1/2 and PI 3-kinase/AKT. Journal of Cell Biology $20021591029-1037$.

17 Korbonits M, Bustin SA, Kojima M, Jordan S, Adams EF, Lowe DG, Kangawa K \& Grossman AB. The expression of the growth hormone secretagogue receptor ligand ghrelin in normal and abnormal human pituitary and other neuroendocrine tumors. Journal of Clinical Endocrinology and Metabolism $2001 \mathbf{8 6}$ $881-887$.

18 Korbonits M, Chitnis MM, Gueorguiev M, Norman D, Rosenfelder N, Suliman M, Jones TH, Noonan K, Fabbri A, Besser GM, Burrin JM \& Grossman AB. The release of leptin and its effect on hormone release from human pituitary adenomas. Clinical Endocrinology $2001 \mathbf{5 4} 781-789$.

19 Favata MF, Horiuchi KY, Manos EJ, Daulerio AJ, Stradley DA, Feeser WS, Van Dyk DE, Pitts WJ, Earl RA, Hobbs F, Copeland RA, Magolda RL, Scherle PA \& Trzaskos JM. Identification of a novel inhibitor of mitogen-activated protein kinase kinase. Journal of Biological Chemistry 1998273 18623-18632.

20 Wang H, Ubl JJ, Stricker R \& Reiser G. Thrombin (PAR-1)-induced proliferation in astrocytes via MAPK involves multiple signaling pathways. American Journal of Physiology Cell Physiology 2002 283 C1351-C1364.

21 Okada T, Sakuma L, Fukui Y, Hazeki O \& Ui M. Blockage of chemotactic peptide-induced stimulation of neutrophils by wortmannin as a result of selective inhibition of phosphatidylinositol 3-kinase. Journal of Biological Chemistry 1994269 $3563-3567$.

22 Chijiwa T, Mishima A, Hagiwara M, Sano M, Hayashi K, Inoue T, Naito K, Toshioko T \& Hidaka H. Inhibition of forskolin-induced 
neurite outgrowth and protein phosphorylation by a newly synthesized selective inhibitor of cyclic AMP-dependent protein kinase, N-[2-(p-bromocinnamylamino)ethyl]-5-isoquinolinesulfonamide (H-89), of PC12D pheochromocytoma cells. Journal of Biological Chemistry 1990265 5267-5272.

23 Kim K, Arai K, Sanno N, Osamura RY, Teramoto A \& Shibasaki T. Ghrelin and growth hormone (GH) secretagogue receptor (GHSR) mRNA expression in human pituitary adenomas. Clinical Endocrinology $2001 \mathbf{5 4} 759-768$.

24 Korbonits M, Jacobs RA, Aylwin SJB, Burrin JM, Dahia PLM, Monson JP, Trainer PJ, Chew SL, Besser GM \& Grossman AB. Expression of the growth hormone secretagogue receptor in pituitary adenomas and other neuroendocrine tumors. Journal of Clinical Endocrinology and Metabolism 199883 3624-3630.

25 Pearson G, Robinson F, Beers GT, Xu BE, Karandikar M, Berman K \& Cobb MH. Mitogen-activated protein (MAP) kinase pathways: regulation and physiological functions. Endocrine Reviews 2001 22 153-183.

26 van Biesen T, Luttrell LM, Hawes BE \& Lefkowitz RJ. Mitogenic signaling via G protein-coupled receptors. Endocrine Reviews 1996 $17698-714$

27 Fowkes RC, Burch J \& Burrin JM. Stimulation of extracellular signal-regulated kinase by pituitary adenylate cyclase-activating polypeptide in alpha T3-1 gonadotrophs. Journal of Endocrinology 2001171 R5-R10.

28 Naor Z, Benard O \& Seger R. Activation of MAPK cascades by G-protein-coupled receptors: the case of gonadotropin-releasing hormone receptor. Trends in Endocrinology and Metabolism 2000 11 91-99.

29 Smith J, Yu R \& Hinkle PM. Activation of MAPK by TRH requires clathrin-dependent endocytosis and PKC but not receptor interaction with beta-arrestin or receptor endocytosis. Molecular Endocrinology $2001151539-1548$.

30 Lania A, Filopanti M, Corbetta S, Losa M, Ballare E, Beck-Peccoz P \& Spada A. Effects of hypothalamic neuropeptides on extracellular signal-regulated kinase (ERK1 and ERK2) cascade in human tumoral pituitary cells. Journal of Clinical Endocrinology and Metabolism $2003 \mathbf{8 8} 1692-1696$.

31 Luttrell LM, Daaka Y \& Lefkowitz RJ. Regulation of tyrosine kinase cascades by G-protein-coupled receptors. Current Opinion in Cell Biology 199911 177-183.

32 Marinissen MJ \& Gutkind JS. G-protein-coupled receptors and signaling networks: emerging paradigms. Trends in Pharmacological Sciences 200122 368-376.
33 Howard AD, Feighner SD, Cully DF, Liberator PA, Arena JP, Rosenblum CI, Hamelin MJ, Hreniuk DL, Palyha OC, Anderson J, Paress PS, Diaz C, Chon M, Liu K, Kulja McKee K, Pong S-S, Chuang LY, Elbrecht A, Dashkevicz M, Heavens R, Rigby M, Sirinathsinghji DJS, Dean DC, Melillo DG, Patchett AA, Nargund R, Griffin PR, DeMartino JA, Gupta SK, Schaeffer JM, Smith RG \& Van der Ploeg LHT. A receptor in pituitary and hypothalamus that functions in growth hormone release. Science $1996 \mathbf{2 7 3}$ 974-977.

34 Kranenburg O \& Moolenaar WH. Ras-MAP kinase signaling by lysophosphatidic acid and other $\mathrm{G}$ protein-coupled receptor agonists. Oncogene 200120 1540-1546.

35 Shah BH, Soh JW \& Catt KJ. Dependence of gonadotropin-releasing hormone-induced neuronal MAPK signaling on epidermal growth factor receptor transactivation. Journal of Biological Chemistry $20032782866-2875$.

36 Schiemann WP \& Nathanson NM. Involvement of protein kinase $\mathrm{C}$ during activation of the mitogen-activated protein kinase cascade by leukemia inhibitory factor. Evidence for participation of multiple signaling pathways. Journal of Biological Chemistry $19942696376-6382$.

37 English J, Pearson G, Wilsbacher J, Swantek J, Karandikar M, Xu S \& Cobb MH. New insights into the control of MAP kinase pathways. Experimental Cell Research 1999253 255-270.

38 Orkin RD, New DI, Norman D, Chew SL, Clark AJL, Grossman AB \& Korbonits M. Rapid desensitisation of the growth hormone secretagogue (ghrelin) receptor to hexarelin in vitro. Journal of Endocrinological Investigation 200326 743-747.

39 Adams EF, Huang B, Buchfelder M, Howard AD, Smith RG, Feighner SD, Van der Ploeg LHT, Bowyers CY \& Fahlbusch R. Presence of growth hormone secretagogue receptor messenger ribonucleic acid in human pituitary tumors and rat GH3 cells. Journal of Clinical Endocrinology and Metabolism $1998 \mathbf{8 3}$ 638-642.

40 Bercu BB, Yang SW, Masuda R \& Walker RF. Role of selected endogenous peptides in growth hormone-releasing hexapeptide activity: analysis of growth hormone-releasing hormone, thyroid hormone-releasing hormone, and gonadotropin-releasing hormone. Endocrinology $19921302579-2586$

Received 9 March 2004

Accepted 19 May 2004 